\title{
Digestibility of amino acids in fish meal and blood-derived protein sources fed to pigs
}

\author{
Chan Sol Park ${ }^{1}$ and Olayiwola Adeola ${ }^{1, *}$
}

* Corresponding Author: Olayiwola Adeola Tel: +1-765-494-4848, Fax: +1-765-494-9346,

E-mail: ladeola@purdue.edu

1 Department of Animal Sciences, Purdue University, West Lafayette, IN 47907, USA

ORCID

Chan Sol Park

https://orcid.org/0000-0001-6294-3854 Olayiwola Adeola

https://orcid.org/0000-0003-2737-7679

Submitted Sept 24, 2021; Revised Oct 25, 2021; Accepted Dec 6, 2021
Objective: An experiment was conducted to determine the standardized ileal digestibility (SID) of amino acids (AA) in fish meal (FM) and blood-derived protein sources including spray-dried porcine plasma (SDPP), porcine red blood cells (PRBC), and blood meal (BM) fed to growing pigs.

Methods: Ten barrows (mean initial body weight of $22.1 \pm 1.54 \mathrm{~kg}$ ) surgically fitted with T-cannulas at the distal ileum were allotted to a duplicated $5 \times 4$ incomplete Latin square design with 5 experimental diets and 4 periods. Four experimental diets were prepared to contain FM, SDPP, PRBC, or BM as the sole source of nitrogen. A nitrogen-free diet was prepared and included to estimate the basal ileal endogenous losses of AA. For the 7-day experimental period, pigs were fed for 5 days as adaptation, and ileal digesta samples were collected for 9 hours on days 6 and 7 .

Results: The SID of crude protein in BM (48.0\%) was less ( $\mathrm{p}<0.05)$ than in FM, SDPP, and PRBC (83.4\%, 83.9\%, and 87.3\%, respectively). Pigs fed the diet containing BM had less $(\mathrm{p}<0.05)$ SID of AA, except isoleucine and proline, than those fed the diet containing FM, SDPP, or PRBC. Among FM, SDPP, and PRBC, there was no difference in the SID of crude protein and all AA, except isoleucine. The SID of isoleucine in PRBC and BM $(62.7 \%$ and $48.3 \%$, respectively) was less $(\mathrm{p}<0.05)$ than in FM and SDPP $(88.0 \%$ and $84.9 \%$, respectively). The SID of lysine in FM, SDPP, PRBC, and BM was $85.4 \%, 84.9 \%$, $89.7 \%$, and $51.9 \%$, respectively.

Conclusion: The SID of most AA was not different among FM, SDPP, and PRBC, but BM had lower SID of most AA than FM, SDPP, and PRBC.

Keywords: Amino Acid; Blood Product; Digestibility; Fish Meal; Protein; Swine

\section{INTRODUCTION}

Protein sources derived from animal byproducts have been used in the modern swine production system, especially for weanling pigs because of their high concentrations of digestible crude protein $(\mathrm{CP})$ and amino acids (AA) as well as functional components. In addition, weanling pigs are susceptible to anti-nutritional factors in soybean meal such as glycinin and $\beta$-conglycinin, leading to a limited inclusion in diets immediately after weaning [1]. Thus, fish meal (FM) has been widely used in diets for weanling pigs which contains high concentrations of $\mathrm{CP}$ and $\mathrm{AA}$ as well as macrominerals such as calcium and phosphorus [2]. However, the concentration of AA as well as their digestibility vary among sources of FM depending on the quality of fish materials and processing conditions [3].

During the meat processing, blood from slaughtered animals can be collected, processed, and dried to produce blood meal (BM), which can be used as a protein source in swine diets. On the other hand, collected blood can be treated with anticoagulant and centrifuged to separate plasma, which can be further processed to produce spray-dried animal 
plasma (SDAP) [4]. It has been reported that dietary supplementation of SDAP improves growth performance by providing immunoglobulins in the intestinal lumen, which bind to the pathogens and reduce the proinflammatory responses and post-weaning diarrhea of pigs [5]. Red blood cells are the byproduct from the production of SDAP, which can be also used in weanling pig diets as a protein source [6]. Red blood cells contain high concentration of CP and lysine but low concentration of isoleucine [7]. Because the major components consisting of blood-derived protein sources are different from each other, digestibility of AA may vary among blood-derived protein sources. However, there is a limited information regarding the comparison of AA digestibility among blood-derived protein sources. Therefore, this study aimed to determine the standardized ileal digestibility (SID) of CP and AA in FM, spray-dried porcine plasma (SDPP), porcine red blood cells (PRBC), and BM fed to growing pigs. The null hypothesis of this study was that the SID of CP and AA are not different among FM and 3 blood-derived protein sources.

\section{MATERIALS AND METHODS}

\section{Animal care}

Protocols of the animal experiment were reviewed and ap- proved by the Purdue University Animal Care and Use Committee (West Lafayette, IN, USA).

\section{Animals, housing, and experimental design}

A total of 10 barrows were surgically fitted with T-cannulas at the distal ileum based on the method reported by Dilger et al [8], followed by 7 days of recovery period. Thereafter, pigs with initial body weight (BW) of $22.1 \pm 1.54 \mathrm{~kg}$ were moved to metabolism crates $\left(1.22 \times 1.22 \mathrm{~m}^{2}\right)$. Pigs were divided into 2 replicates based on BW (i.e., heaviest 5 pigs and lightest 5 pigs) and allotted to a duplicated $5 \times 4$ incomplete Latin square design with 5 experimental diets and 4 periods. Pigs had free access to water via nipple drinkers.

\section{Experimental diets, feeding, and sample collection}

Five experimental diets were prepared based on cornstarch and sucrose (Table 1). Four diets were prepared to contain FM, SDPP, PRBC, or BM as the sole source of nitrogen $(\mathrm{N})$ with providing $160 \mathrm{~g} / \mathrm{kg} \mathrm{CP}$ in each diet. Fish meal used in this experiment was mechanically extracted from menhaden and purchased from a local supplier. Blood-derived protein sources in this experiment were obtained from Darling Ingredient Inc. (Cold Spring, KY, USA). Nitrogen-free diet (NFD) was prepared to estimate the basal ileal endogenous losses (BEL) of CP and AA in pigs. Soybean oil and cellulose

Table 1. Ingredient composition of experimental diets containing fish meal, spray-dried porcine plasma, porcine red blood cells, and blood meal (g/kg as-fed basis)

\begin{tabular}{|c|c|c|c|c|c|}
\hline Ingredient & FM & SDPP & PRBC & BM & NFD \\
\hline Corn starch & 320.0 & 345.2 & 367.3 & 363.3 & 316.0 \\
\hline Sucrose & 300.0 & 300.0 & 300.0 & 300.0 & 500.0 \\
\hline Fish meal & 246.0 & 0.0 & 0.0 & 0.0 & 0.0 \\
\hline Porcine red blood cells & 0.0 & 0.0 & 164.0 & 0.0 & 0.0 \\
\hline Blood meal & 0.0 & 0.0 & 0.0 & 168.0 & 0.0 \\
\hline Ground limestone & 0.0 & 17.8 & 13.0 & 13.0 & 13.0 \\
\hline Monocalcium phosphate & 0.0 & 12.0 & 21.7 & 21.7 & 23.5 \\
\hline Salt & 4.0 & 4.0 & 4.0 & 4.0 & 0.0 \\
\hline Potassium carbonate & 0.0 & 0.0 & 0.0 & 0.0 & 2.6 \\
\hline Magnesium oxide & 0.0 & 0.0 & 0.0 & 0.0 & 2.0 \\
\hline Chromic oxide premix ${ }^{3)}$ & 25.0 & 25.0 & 25.0 & 25.0 & 25.0 \\
\hline Total & $1,000.0$ & $1,000.0$ & $1,000.0$ & $1,000.0$ & $1,000.0$ \\
\hline
\end{tabular}

FM, fish meal; SDPP, spray-dried porcine plasma; PRBC, porcine red blood cells; BM, blood meal; NFD, nitrogen-free diet.

1) Solka-Floc 40 FCC (International Fiber Corporation, Urbana, OH, USA).

2) Provided the following quantities per kilogram of complete diet: vitamin $A, 8,575 \mathrm{IU}$; vitamin $\mathrm{D}_{3}, 4,300 \mathrm{IU}$; vitamin $\mathrm{E}, 28.6 \mathrm{IU}$; menadione, 7.30 mg; riboflavin, 9.15 mg; D-pantothenic acid, 18.3 mg; niacin, 73.5 mg; choline chloride, 1,285 mg; vitamin $B_{12}, 0.02$ mg; biotin, 0.09 mg; thiamine mononitrate, 3.67 $\mathrm{mg}$; folic acid, $1.65 \mathrm{mg}$; pyridoxine hydrochloride, $5.50 \mathrm{mg} ; \mathrm{I}, 1.85 \mathrm{mg}$ as ethylenediamine dihydroiodide; $\mathrm{Mn}, 180 \mathrm{mg}$ as manganous oxide; Cu, $7.40 \mathrm{mg}$ as copper sulfate; Fe, $73.5 \mathrm{mg}$ as ferrous sulfate; $\mathrm{Zn}, 180 \mathrm{mg}$ as zinc oxide; and Se, $0.43 \mathrm{mg}$ as sodium selenite.

${ }^{3)}$ Prepared by adding $5 \mathrm{~g}$ chromic oxide to $20 \mathrm{~g}$ sucrose. 
were each added at $50 \mathrm{~g} / \mathrm{kg}$ to supply energy and dietary fiber, respectively. Experimental diets were formulated to meet or exceed the vitamin and mineral requirement estimates suggested in National Research Council (NRC) [9]. Chromic oxide was added to all diets at $5 \mathrm{~g} / \mathrm{kg}$ as an index marker.

Individual BW of pigs were measured at the beginning of each experimental period to calculate the daily amount of feed offered which was $4 \%$ of mean BW within replicates. Pigs were fed twice a day at 0800 and 1700 hours. For the 7-day experimental period, pigs were fed for 5 days as adaptation, and ileal digesta samples were collected for 9 hours on days 6 and 7. Ileal digesta samples were collected via Tcannulas by attaching plastic sample bags (Whirl-Pak bag; NASCO, Fort Atkinson, WI, USA) containing $10 \mathrm{~mL}$ of $10 \%$ formic acid. Attached plastic samples bags were changed every 30 minutes and immediately stored at $-20^{\circ} \mathrm{C}$. At the end of each experimental period, frozen ileal digesta samples were slightly thawed, pooled within pigs, and subsampled. Collected subsamples were stored at $-20^{\circ} \mathrm{C}$ before further analyses.

\section{Chemical analyses}

Frozen ileal digesta samples were freeze dried before the chemical analyses. Test ingredients, experimental diets, and freeze-dried ileal digesta samples were finely ground $(<0.75$ $\mathrm{mm}$ ) using a centrifugal grinder (ZM 200; Retsch GmbH, Haan, Germany). The concentrations of dry matter (DM) in ground ingredients, diets, and freeze-dried ileal digesta samples were analyzed by drying at $105^{\circ} \mathrm{C}$ for $24 \mathrm{~h}$ in a forcedair drying oven (Precision Scientific Co., Chicago, IL, USA; method 934.0) [10]. A combustion method was used to analyze the concentrations of $\mathrm{N}$ in ground samples (TruMac N; LECO Corp., St. Joseph, MI, USA; method 990.03) [11], and the concentration of $\mathrm{CP}$ was calculated by multiplying the $\mathrm{N}$ concentration by 6.25 . To digest samples for the analysis of AA, samples of test ingredients, experimental diets, and ileal digesta were hydrolyzed by $6 \mathrm{M} \mathrm{HCl}$ (or $\mathrm{BaOH}$ for tryptophan analysis) at $110^{\circ} \mathrm{C}$ for $24 \mathrm{~h}$ under $\mathrm{N}$ atmosphere. An oxidation of samples using performic acid was conducted for the analysis of methionine and cysteine before digestion. High-performance liquid chromatography was used to determine the concentrations of AA in digested samples after postcolumn derivatization (method 982.30 E [a, b, c]) [10]. The analysis of AA was conducted at University of Missouri Agricultural Experiment Station Chemical Laboratories (Columbia, MO, USA). The concentrations of acidhydrolyzed ether extract (AEE; method 954.02) [10] and ash (method 942.05) [10] in test ingredients were analyzed. Experimental diets and ileal digesta were analyzed for the concentration of chromium (Cr) using a spectrophotometer (Spark 10M; Tecan Group Ltd., Männedorf, Switzerland) at $450 \mathrm{~nm}$ of absorbance after the wet digestion in nitric acid and 70\% perchloric acid [12].

\section{Calculations}

The apparent ileal digestibility (AID) of CP and AA in test ingredients were calculated by the index method suggested in Kong and Adeola [13]:

$$
\operatorname{AID}(\%)=100 \times\left[1-\left(\mathrm{Cr}_{\text {in }} / \mathrm{Cr}_{\text {out }}\right) \times\left(\mathrm{AA}_{\text {out }} / \mathrm{AA}_{\text {in }}\right)\right] \text {, }
$$

where $\mathrm{Cr}_{\text {in }}$ and $\mathrm{Cr}_{\text {out }}$ represent the concentration of $\mathrm{Cr}(\mathrm{g} / \mathrm{kg}$ $\mathrm{DM})$ in experimental diets and ileal digesta, respectively; $\mathrm{AA}_{\mathrm{in}}$ and $\mathrm{AA}_{\text {out }}$ represent the concentration of $\mathrm{CP}$ or $\mathrm{AA}(\mathrm{g} / \mathrm{kg}$ $\mathrm{DM})$ in experimental diets and ileal digesta, respectively. Data from pigs fed NFD were used to estimate the BEL $[\mathrm{g} / \mathrm{kg}$ $\mathrm{DM}$ intake (DMI)] of $\mathrm{CP}$ and $\mathrm{AA}$ using the following equation:

$$
\operatorname{BEL}(\mathrm{g} / \mathrm{kg} \mathrm{DMI})=\mathrm{AA}_{\text {out }} \times\left(\mathrm{Cr}_{\text {in }} / \mathrm{Cr}_{\text {out }}\right) .
$$

To calculate the SID of CP and AA in test ingredients, the $\mathrm{AID}$ of $\mathrm{CP}$ and $\mathrm{AA}$ were corrected for the estimated BEL of $\mathrm{CP}$ and $\mathrm{AA}$ using the following equation:

$$
\operatorname{SID}(\%)=\mathrm{AID}+\left[100 \times\left(\mathrm{BEL} / \mathrm{AA}_{\mathrm{in}}\right)\right] \text {. }
$$

\section{Statistical analyses}

Data were tested for normality by univariate procedure of SAS (version 9.4; SAS Inst. Inc., Cary, NC, USA), and data outside of 2.5 times interquartile range were considered outliers. Thereafter, data were analyzed by mixed linear models procedure of SAS. Model included experimental diet as fixed variable and replicate, period within replicate, and pig within replicate as random variables. Pairwise comparison with the Tukey's adjustment was conducted to separate the estimated least squares means among experimental diets. Experimental unit was the individual pig. Significance of the model and difference was determined by $\mathrm{p}<0.05$.

\section{RESULTS}

All pigs were healthy throughout except one pig fed NFD during the last experimental period, which was removed from experiment. Also, data from 2 pigs fed NFD and 1 pig fed the diet containing PRBC were detected as outliers and therefore treated as missing observations in the dataset.

On an as-fed basis, the concentration of CP in test ingredients ranged from $658 \mathrm{~g} / \mathrm{kg}$ for FM to $968 \mathrm{~g} / \mathrm{kg}$ for PRBC (Table 2). The concentration of AEE in SDPP was $26.2 \mathrm{~g} / \mathrm{kg}$, whereas that in PRBC was $8.3 \mathrm{~g} / \mathrm{kg}$. Fish meal had the greatest concentration of ash at $201.4 \mathrm{~g} / \mathrm{kg}$. The analyzed concentrations of AA in experimental diets are close to the calculated values based on the analyzed concentrations of AA in test 
ingredients (Table 3).

The AID of CP and AA, except isoleucine, in BM were less $(p<0.05)$ than in the other test ingredients (Table 4). There was no difference in the AID of AA among FM, SDPP, and PRBC, except isoleucine, methionine, and cysteine. Pigs fed the diets containing PRBC and BM had less $(\mathrm{p}<0.05)$ AID of isoleucine than those fed the diets containing FM and SDPP. The AID of methionine in FM was greater $(p<0.05)$ than in SDPP, but not different from the value in PRBC. Pigs fed the SDPP diet had greater $(p<0.05)$ AID of cysteine than those fed the PRBC diet, which was not different from FM.

The BEL of CP in pigs fed NFD was $19.9 \mathrm{~g} / \mathrm{kg}$ DMI (Table 5). The BEL of indispensable AA ranged from $89 \mathrm{mg} / \mathrm{kg}$ DMI for methionine to $666 \mathrm{mg} / \mathrm{kg}$ DMI for valine. The SID of CP in BM was less $(\mathrm{p}<0.05)$ than in FM, SDPP, and PRBC (Table 6). Pigs fed the diet containing BM had less $(\mathrm{p}<0.05)$ SID of $\mathrm{AA}$, except isoleucine and proline, than those fed the diet containing FM, SDPP, or PRBC. Among FM, SDPP, and $\mathrm{PRBC}$, there was no difference in the SID of $\mathrm{CP}$ and all $\mathrm{AA}$, except isoleucine. The SID of isoleucine in PRBC and BM was less $(\mathrm{p}<0.05)$ than in FM and SDPP.

Table 2. Analyzed concentration of nutrients and gross energy in fish meal, spray-dried porcine plasma, porcine red blood cells, and blood meal ( $\mathrm{g} / \mathrm{kg}$ as-fed basis)

\begin{tabular}{|c|c|c|c|c|}
\hline Nutrient & FM & SDPP & PRBC & BM \\
\hline Dry matter & 911 & 936 & 896 & 911 \\
\hline Gross energy (MJ/kg) & 18.3 & 20.2 & 22.0 & 22.4 \\
\hline Crude protein ${ }^{1)}$ & 658 & 826 & 968 & 944 \\
\hline Acid-hydrolyzed ether extract & 86.9 & 26.2 & 8.3 & 20.3 \\
\hline Ash & 201.4 & 72.7 & 9.8 & 22.5 \\
\hline \multicolumn{5}{|l|}{ Indispensable amino acid } \\
\hline Arginine & 36.6 & 47.4 & 39.0 & 48.6 \\
\hline Histidine & 12.2 & 26.7 & 73.7 & 49.6 \\
\hline Isoleucine & 25.5 & 30.3 & 5.8 & 36.7 \\
\hline Leucine & 41.8 & 78.3 & 129.0 & 96.5 \\
\hline Lysine & 47.1 & 69.0 & 81.9 & 76.6 \\
\hline Methionine & 16.9 & 6.9 & 7.2 & 11.7 \\
\hline Phenylalanine & 24.3 & 46.6 & 65.5 & 55.9 \\
\hline Threonine & 24.5 & 45.8 & 28.8 & 43.0 \\
\hline Tryptophan & 6.2 & 14.9 & 14.8 & 9.0 \\
\hline Valine & 29.2 & 55.0 & 89.4 & 61.0 \\
\hline \multicolumn{5}{|l|}{ Dispensable amino acid } \\
\hline Alanine & 39.7 & 43.5 & 77.6 & 67.0 \\
\hline Aspartic acid & 53.6 & 76.2 & 110.0 & 81.5 \\
\hline Cysteine & 5.1 & 27.6 & 6.9 & 14.1 \\
\hline Glutamic acid & 77.8 & 113.4 & 75.2 & 87.7 \\
\hline Glycine & 48.6 & 28.6 & 44.7 & 34.7 \\
\hline Proline & 29.5 & 48.8 & 33.4 & 37.4 \\
\hline Serine & 21.4 & 42.5 & 37.1 & 34.6 \\
\hline Tyrosine & 17.2 & 42.3 & 20.3 & 30.8 \\
\hline
\end{tabular}

FM, fish meal; SDPP, spray-dried porcine plasma; PRBC, porcine red blood cells; BM, blood meal.

${ }^{1)}$ Nitrogen $\times 6.25$.
Table 3. Analyzed concentration of dry matter, crude protein, and amino acids in experimental diets containing fish meal, spray-dried porcine plasma, porcine red blood cells, and blood meal ( $\mathrm{g} / \mathrm{kg}$ as-fed basis)

\begin{tabular}{|c|c|c|c|c|c|}
\hline Nutrient & FM & SDPP & PRBC & BM & NFD \\
\hline Dry matter & 952 & 948 & 945 & 948 & 963 \\
\hline Crude protein ${ }^{1)}$ & 180 & 170 & 166 & 154 & 11 \\
\hline \multicolumn{6}{|c|}{ Indispensable amino acid } \\
\hline Arginine & 9.2 & 8.8 & 5.9 & 7.4 & 0.0 \\
\hline Histidine & 3.1 & 5.0 & 10.5 & 7.9 & 0.0 \\
\hline Isoleucine & 6.7 & 6.0 & 1.3 & 6.2 & 0.0 \\
\hline Leucine & 10.9 & 15.3 & 19.4 & 16.1 & 0.1 \\
\hline Lysine & 12.3 & 13.5 & 12.8 & 12.5 & 0.1 \\
\hline Methionine & 4.3 & 1.3 & 1.1 & 1.9 & 0.1 \\
\hline Phenylalanine & 6.2 & 9.1 & 10.0 & 9.2 & 0.1 \\
\hline Threonine & 6.2 & 8.8 & 4.8 & 7.0 & 0.0 \\
\hline Tryptophan & 1.7 & 2.9 & 1.9 & 0.8 & 0.0 \\
\hline Valine & 7.8 & 10.9 & 13.5 & 10.1 & 0.1 \\
\hline \multicolumn{6}{|c|}{ Dispensable amino acid } \\
\hline Alanine & 10.6 & 8.7 & 11.6 & 11.0 & 0.1 \\
\hline Aspartic acid & 14.0 & 15.0 & 16.9 & 13.5 & 0.1 \\
\hline Cysteine & 1.3 & 5.4 & 1.4 & 2.3 & 0.0 \\
\hline Glutamic acid & 20.8 & 22.6 & 12.7 & 14.5 & 0.1 \\
\hline Glycine & 12.8 & 5.7 & 6.9 & 5.7 & 0.1 \\
\hline Proline & 8.0 & 9.2 & 5.3 & 5.7 & 0.2 \\
\hline Serine & 5.3 & 7.8 & 5.9 & 5.7 & 0.1 \\
\hline Tyrosine & 3.8 & 6.2 & 2.7 & 3.9 & 0.0 \\
\hline
\end{tabular}

FM, fish meal; SDPP, spray-dried porcine plasma; PRBC, porcine red blood cells; BM, blood meal; NFD, nitrogen-free diet.

1) Nitrogen $\times 6.25$.

\section{DISCUSSION}

The analyzed CP, AA, and ash concentrations in FM are consistent with the previously reported values $[9,14,15]$. In addition, the concentration of AEE in FM also agrees with the values reported in Casas et al [14] and Lagos and Stein [15]. The FM used in the current study is representative due to similarity in AA concentration for FM reported in previous studies $[9,14,15]$. The concentration of AA in SDPP are comparable to the values for plasma protein [9] and the values for SDAP [16] despite the differences in source of blood plasma. Torrallardona [5] reported that the concentration of AA in SDPP was not substantially different from that in spraydried bovine plasma (SDBP). However, SDPP used in the current study has greater indispensable AA and lower ash concentrations compared to SDPP used in Wu et al [17], which may be due to the differences in processing conditions [5]. Compared to nutrient composition of SDAP in previous studies $[9,16,17]$, SDPP used in the current study contains slightly greater $\mathrm{CP}$ and lower ash. This observation is consistent with Torrallardona [5] who suggested that the concentration of CP in SDAP is negatively related to the concentration of ash. The concentration of indispensable AA in $\mathrm{PRBC}$ agrees with the values for spray-dried blood cells $[6,16]$. 
Table 4. Apparent ileal digestibility (\%) of crude protein and amino acids in fish meal, spray-dried porcine plasma, porcine red blood cells, and blood meal fed to growing pigs ${ }^{1)}$

\begin{tabular}{|c|c|c|c|c|c|c|}
\hline Item & FM & SDPP & PRBC & BM & SEM & p-value \\
\hline Crude protein & $72.8^{a}$ & $72.8^{a}$ & $76.0^{a}$ & $35.8^{b}$ & 3.43 & $<0.001$ \\
\hline \multicolumn{7}{|l|}{ Indispensable amino acid } \\
\hline Arginine & $84.1^{a}$ & $80.9^{a}$ & $78.7^{a}$ & $43.5^{b}$ & 3.71 & $<0.001$ \\
\hline Histidine & $79.5^{\mathrm{a}}$ & $83.2^{\mathrm{a}}$ & $88.8^{\mathrm{a}}$ & $44.3^{b}$ & 3.38 & $<0.001$ \\
\hline Isoleucine & $83.5^{\mathrm{a}}$ & $79.9^{\mathrm{a}}$ & $39.7^{b}$ & $43.5^{b}$ & 4.43 & $<0.001$ \\
\hline Leucine & $83.8^{\mathrm{a}}$ & $82.8^{a}$ & $87.0^{\mathrm{a}}$ & $43.1^{b}$ & 3.18 & $<0.001$ \\
\hline Lysine & $81.5^{\mathrm{a}}$ & $81.3^{a}$ & $85.9^{a}$ & $48.0^{b}$ & 3.14 & $<0.001$ \\
\hline Methionine & $86.9^{a}$ & $75.1^{b}$ & $80.9^{a b}$ & $55.0^{c}$ & 3.03 & $<0.001$ \\
\hline Phenylalanine & $81.2^{\mathrm{a}}$ & $82.6^{a}$ & $86.7^{\mathrm{a}}$ & $42.2^{b}$ & 3.33 & $<0.001$ \\
\hline Threonine & $75.9^{\mathrm{a}}$ & $72.4^{a}$ & $69.0^{\mathrm{a}}$ & $40.4^{b}$ & 3.76 & $<0.001$ \\
\hline Tryptophan & $84.3^{a}$ & $81.8^{a}$ & $85.3^{a}$ & $44.3^{b}$ & 3.74 & $<0.001$ \\
\hline Valine & $79.7^{\mathrm{a}}$ & $75.3^{\mathrm{a}}$ & $84.6^{a}$ & $37.8^{\mathrm{b}}$ & 3.37 & $<0.001$ \\
\hline \multicolumn{7}{|l|}{ Dispensable amino acid } \\
\hline Alanine & $81.1^{\mathrm{a}}$ & $78.1^{\mathrm{a}}$ & $86.0^{\mathrm{a}}$ & $41.6^{b}$ & 3.34 & $<0.001$ \\
\hline Aspartic acid & $70.9^{a}$ & $74.3^{\mathrm{a}}$ & $83.8^{\mathrm{a}}$ & $35.6^{b}$ & 3.45 & $<0.001$ \\
\hline Cysteine & $57.2^{\mathrm{ab}}$ & $74.4^{\mathrm{a}}$ & $51.3^{b}$ & $24.4^{c}$ & 4.91 & $<0.001$ \\
\hline Glutamic acid & $81.3^{\mathrm{a}}$ & $76.6^{a}$ & $77.1^{\mathrm{a}}$ & $42.3^{b}$ & 3.51 & $<0.001$ \\
\hline Glycine & $70.0^{\mathrm{a}}$ & $57.1^{\mathrm{a}}$ & $68.6^{a}$ & $20.5^{b}$ & 5.46 & $<0.001$ \\
\hline Proline & $25.9^{a}$ & $42.3^{a}$ & $28.4^{\mathrm{a}}$ & $-73.9^{b}$ & 22.56 & 0.003 \\
\hline Serine & $73.5^{\mathrm{a}}$ & $71.8^{\mathrm{a}}$ & $77.3^{\mathrm{a}}$ & $40.7^{b}$ & 3.42 & $<0.001$ \\
\hline Tyrosine & $80.4^{a}$ & $81.4^{\mathrm{a}}$ & $75.3^{\mathrm{a}}$ & $44.5^{b}$ & 3.93 & $<0.001$ \\
\hline
\end{tabular}

FM, fish meal; SDPP, spray-dried porcine plasma; PRBC, porcine red blood cells; BM, blood meal; SEM, standard error of the mean.

1) Each least squares mean represents 8 observations except for pigs fed PRBC (7 observations).

${ }^{a-c}$ Within a row, means with different superscripts differ $(p<0.05)$.

Table 5. Basal ileal endogenous losses ( $\mathrm{mg} / \mathrm{kg}$ dry matter intake) of crude protein and amino acids in growing pigs fed nitrogen-free diet ${ }^{1)}$

\begin{tabular}{|c|c|c|}
\hline Item & BEL & SD \\
\hline Crude protein ${ }^{2)}$ (g/kg DMI) & 19.9 & 4.30 \\
\hline \multicolumn{3}{|l|}{ Indispensable amino acid } \\
\hline Arginine & 615 & 187.5 \\
\hline Histidine & 187 & 35.9 \\
\hline Isoleucine & 317 & 41.6 \\
\hline Leucine & 566 & 83.1 \\
\hline Lysine & 511 & 80.0 \\
\hline Methionine & 89 & 16.1 \\
\hline Phenylalanine & 338 & 44.2 \\
\hline Threonine & 661 & 58.7 \\
\hline Tryptophan & 111 & 22.4 \\
\hline Valine & 666 & 47.6 \\
\hline \multicolumn{3}{|l|}{ Dispensable amino acid } \\
\hline Alanine & 561 & 80.7 \\
\hline Aspartic acid & 816 & 103.3 \\
\hline Cysteine & 199 & 22.4 \\
\hline Glutamic acid & 989 & 136.2 \\
\hline Glycine & 1459 & 572.7 \\
\hline Proline & 5015 & 2769.0 \\
\hline Serine & 589 & 61.5 \\
\hline Tyrosine & 245 & 33.5 \\
\hline
\end{tabular}

BEL, basal ileal endogenous loss; SD, standard deviation; DMI, dry matter intake.

1) Each mean represents 5 observations.

2) Nitrogen $\times 6.25$.
Because blood cells are almost exclusively composed of hemoglobin [4], it is assumed that nutrient compositions of blood cells products are relatively consistent among sources regardless of species origins. The concentration of $\mathrm{CP}$ in $\mathrm{BM}$ is slightly greater than previously reported $\mathrm{CP}$ concentrations ranging from 887 to $917 \mathrm{~g} / \mathrm{kg}$ as-fed basis, whereas the concentration of indispensable AA, except isoleucine and leucine, is close to the previously reported values $[9,16,18]$. Compared to the reference values, the concentration of isoleucine was greater, but that of leucine was lower in BM used in the current study. This may be due to the reduced inclusion rate of blood cells because blood cells contain low concentration of isoleucine and high concentration of leucine. In addition, BM used in the current study was produced using a mixture of blood collected from both beef and pork productions, and therefore, variations in AA concentrations might be related to the ratio between bovine and porcine blood.

Fish meal and SDPP have been widely used in diets for weanling pigs due to their high quality of protein and favorable AA contents for animal growth $[2,19]$. Although the use of PRBC in swine diets is not as common as FM or SDPP, practical applications in weanling pig diets have been reported in previous publications $[6,7,20]$. Even though animal protein sources have been generally used for weanling pigs, they have been also used in growing pig diets depending on the availability of feed ingredients or functional purposes. Therefore, 
Table 6. Standardized ileal digestibility (\%) of crude protein and amino acids in fish meal, spray-dried porcine plasma, porcine red blood cells, and blood meal fed to growing pigs ${ }^{1)}$

\begin{tabular}{|c|c|c|c|c|c|c|}
\hline Item & FM & SDPP & PRBC & BM & SEM & p-value \\
\hline Crude protein & $83.4^{a}$ & $83.9^{a}$ & $87.3^{\mathrm{a}}$ & $48.0^{b}$ & 3.43 & $<0.001$ \\
\hline \multicolumn{7}{|c|}{ Indispensable amino acid } \\
\hline Arginine & $90.4^{\mathrm{a}}$ & $87.6^{\mathrm{a}}$ & $88.5^{a}$ & $51.4^{b}$ & 3.71 & $<0.001$ \\
\hline Histidine & $85.3^{\mathrm{a}}$ & $86.7^{\mathrm{a}}$ & $90.5^{\mathrm{a}}$ & $46.5^{b}$ & 3.38 & $<0.001$ \\
\hline Isoleucine & $88.0^{\mathrm{a}}$ & $84.9^{a}$ & $62.7^{b}$ & $48.3^{b}$ & 4.43 & $<0.001$ \\
\hline Leucine & $88.8^{a}$ & $86.3^{\mathrm{a}}$ & $89.8^{a}$ & $46.5^{b}$ & 3.18 & $<0.001$ \\
\hline Lysine & $85.4^{\mathrm{a}}$ & $84.9^{a}$ & $89.7^{\mathrm{a}}$ & $51.9^{b}$ & 3.14 & $<0.001$ \\
\hline Methionine & $88.9^{\mathrm{a}}$ & $81.7^{\mathrm{a}}$ & $88.6^{a}$ & $59.5^{b}$ & 3.03 & $<0.001$ \\
\hline Phenylalanine & $86.4^{a}$ & $86.1^{\mathrm{a}}$ & $89.9^{a}$ & $45.7^{b}$ & 3.33 & $<0.001$ \\
\hline Threonine & $86.1^{\mathrm{a}}$ & $79.6^{\mathrm{a}}$ & $82.0^{\mathrm{a}}$ & $49.3^{b}$ & 3.76 & $<0.001$ \\
\hline Tryptophan & $90.5^{\mathrm{a}}$ & $85.4^{\mathrm{a}}$ & $90.8^{a}$ & $56.8^{b}$ & 3.74 & $<0.001$ \\
\hline Valine & $87.8^{\mathrm{a}}$ & $81.1^{\mathrm{a}}$ & $89.3^{\mathrm{a}}$ & $44.0^{b}$ & 3.37 & $<0.001$ \\
\hline \multicolumn{7}{|c|}{ Dispensable amino acid } \\
\hline Alanine & $86.1^{\mathrm{a}}$ & $84.2^{\mathrm{a}}$ & $90.5^{\mathrm{a}}$ & $46.4^{b}$ & 3.34 & $<0.001$ \\
\hline Aspartic acid & $76.5^{\mathrm{a}}$ & $79.5^{\mathrm{a}}$ & $88.4^{a}$ & $41.3^{b}$ & 3.45 & $<0.001$ \\
\hline Cysteine & $71.7^{\mathrm{a}}$ & $77.8^{\mathrm{a}}$ & $64.7^{\mathrm{a}}$ & $32.6^{b}$ & 4.91 & $<0.001$ \\
\hline Glutamic acid & $85.8^{\mathrm{a}}$ & $80.7^{\mathrm{a}}$ & $84.5^{\mathrm{a}}$ & $48.8^{b}$ & 3.51 & $<0.001$ \\
\hline Glycine & $80.9^{a}$ & $81.4^{\mathrm{a}}$ & $88.6^{a}$ & $44.7^{b}$ & 5.46 & $<0.001$ \\
\hline Proline & $85.6^{\mathrm{ab}}$ & $94.0^{\mathrm{a}}$ & $117.9^{\mathrm{a}}$ & $9.5^{\mathrm{b}}$ & 22.56 & 0.009 \\
\hline Serine & $84.1^{\mathrm{a}}$ & $79.0^{\mathrm{a}}$ & $86.7^{\mathrm{a}}$ & $50.5^{b}$ & 3.42 & $<0.001$ \\
\hline Tyrosine & $86.6^{\mathrm{a}}$ & $85.2^{\mathrm{a}}$ & $83.9^{\mathrm{a}}$ & $50.5^{b}$ & 3.93 & $<0.001$ \\
\hline
\end{tabular}

FM, fish meal; SDPP, spray-dried porcine plasma; PRBC, porcine red blood cells; BM, blood meal; SEM, standard error of the mean.

1) Each least squares mean represents 8 observations except for pigs fed PRBC (7 observations).

$a, b$ Within a row, means with different superscripts differ $(p<0.05)$.

the current experiment was conducted to determine the SID values using growing pigs to provide necessary information required to properly use FM and blood-derived protein sources in diets for growing pigs.

The SID of CP and AA, except isoleucine, were not different among FM, SDPP, and PRBC, which may indicate that FM, SDPP, and PRBC tested in this experiment have similar AA availability for pigs. However, it should be noted that the functional properties of FM, SDPP, and PRBC are different when fed to weanling pigs despite the similarity of SID of AA. Fish meal has been used in weanling pig diets mainly because it contains highly digestible and balanced AA as well as poly unsaturated fatty acids [2] and because it is a cost-effective protein source compared to SDPP. On the other hand, SDPP has been added in diets for weanling pigs to improve the immune status of pigs by providing exogenous immunoglobulins, leading to the reduction of post-weaning diarrhea and the increase in growth performance [5]. Therefore, together with the SID of AA in FM and SDPP, their functional properties should be considered when formulating diets containing FM and SDPP. The reason for less SID of isoleucine in PRBC compared to FM and SDPP remains unclear; perhaps this is partly due to the low concentration of isoleucine (5.8 $\mathrm{g} / \mathrm{kg}$ as-fed basis) in PRBC, which translates to less than $1 \mathrm{~g} / \mathrm{kg}$ of diet. Such a low dietary concentration is susceptible to attendant analytical errors. This observation implies that crystalline isoleucine or isoleucine-rich feed ingredient is required to prevent potential isoleucine deficiency when feeding PRBC to pigs.

The BEL of CP and AA observed in this study are comparable to the values summarized in previous studies $[9,21,22]$. The BEL of proline was relatively greater than the BEL of other AA, which may be due to the altered AA metabolism in the gastrointestinal tract caused by deficiency of AA in pigs fed NFD [22]. The SID of CP and AA in FM are close to the SID values of menhaden FM reported in Rojas et al [23] and Casas et al [14], but somewhat greater than SID values of menhaden FM presented by Lagos and Stein [15]. This inconsistency may be due to the differences in BW of pigs used in experiments or FM products such as processing conditions or oxidation [3]. In addition, Jones et al [24] reported that the inclusion rate of fish solubles in FM may influence the nutritional values of FM, although growth performance was not affected by the inclusion of fish solubles.

The SID of CP and AA in SDPP observed in the current study are in agreement with NRC [9] and Wu et al [17]; however, the SID values in SDPP are less than the values reported in Gottlob et al [25] and Almeida et al [16], in which SDAP was used as a test ingredient. In a meta-analysis study reported by Balan et al [19], there was no difference between 
SDPP and SDBP in growth performance of weanling pigs, but weanling pigs fed SDAP had lower growth performance than those fed SDPP and SDBP. However, it should be noted that beneficial effect of feeding plasma protein is likely due to its immunoglobulin content, which may mitigate the inflammation of weanling pigs [5]. In other words, greater beneficial effect of SDPP compared to SDAP may not indicate the greater digestibility of AA in SDPP than SDAP. Further research is needed to systemically compare the overall nutritional quality of plasma protein sources focusing on digestible AA contents and bioactive proteins (i.e., immunoglobulins), all of which directly influence the growth performance of weanling pigs.

The information for the SID of CP and AA in PRBC as well as blood cells is scarce, but the SID of CP and AA in $\mathrm{PRBC}$ are less than those in spray-dried blood cells reported by Almeida et al [16]. This difference is likely due to variations in processing of blood cells after centrifugation. Because the concentration of AA in PRBC is close to those reported by Almeida et al [16], it is assumed that the high temperature during the drying process might negatively affect proteins and AA in PRBC, resulting in a slight reduction of SID of AA. However, the potential heat damage on PRBC may not be as severe as on BM in the current study.

Several processes in the production of BM, such as heat treatment, $\mathrm{pH}$ control, or filtration, may negatively affect the availability of protein and AA [4]. In addition, high temperature during the drying process may cause the Maillard reaction which reduces the digestibility of lysine in feed ingredients [26]. Therefore, it is speculated that proteins in BM used in the current study was damaged during the production process, resulting in lower SID of most AA than FM as well as the other blood-derived sources. Due to the high BEL of proline and reduced digestibility by heat damage, the SID of proline was considerably lower than the other AA. Moreover, the SID of CP and AA in BM observed in the current study were lower than the values reported in the previous studies $[9,16,18]$, which may be another evidence of protein denaturation in BM.

\section{CONCLUSION}

Based on the results of this experiment, the null hypothesis of this study was rejected, and it was concluded that the SID of $\mathrm{CP}$ and most AA in BM were less than in FM, SDPP, and PRBC. The SID of CP and AA, except isoleucine, were not different among FM, SDPP, and PRBC. The SID of isoleucine in PRBC and BM was less than in FM and SDPP. This study revealed that FM, SDPP, and PRBC have similar digestibility of AA, except isoleucine, all of which contain high quality AA balance to support the optimal growth of pigs.

\section{CONFLICT OF INTEREST}

We certify that there is no conflict of interest with any financial organization regarding the material discussed in the manuscript.

\section{FUNDING}

The authors received no financial support for the study reported in this article.

\section{ACKNOWLEDGMENTS}

The authors sincerely thank Patricia A. Jaynes, Brian D. Ford, and Dr. Darryl Ragland (Purdue University, West Lafayette, IN) for their contributions to this study.

\section{REFERENCES}

1. DeRouchey JM, Goodband RD, Tokach MD, Nelssen JL, Dritz SS. Nursery swine nutrient recommendations and feeding management. In: Meisinger DJ, editor. National swine nutrition guide. Ames, IA, USA: U. S. Pork Center of Excellence; 2010. p. 65-79.

2. Cho JH, Kim IH. Fish meal - nutritive value. J Anim Physiol Anim Nutr 2011;95:685-92. https://doi.org/10.1111/j.14390396.2010.01109.x

3. Chiba LI. Protein supplements. In: Lewis AJ, Southern LL, editors. Swine nutrition. 2nd ed. Washington, DC, USA: CRC Press; 2001. p. 803-37.

4. Toldrà M, Lynch SA, Couture R, Álvarez C. Blood proteins as functional ingredients. In: Galanakis CM, editor. Sustainable meat production and processing. San Diego, CA, USA: Academic Press; 2019. pp. 85-101.

5. Torrallardona D. Spray dried animal plasma as an alternative to antibiotics in weanling pigs - A review. Asian-Australas J Anim Sci 2010;23:131-48. https://doi.org/10.5713/ajas.2010. 70630

6. DeRouchey JM, Tokach MD, Nelssen JL, et al. Comparison of spray-dried blood meal and blood cells in diets for nursery pigs. J Anim Sci 2002;80:2879-86. https://doi.org/10.2527/ 2002.80112879x

7. Waguespack AM, Dean DW, Bidner TD, Southern LL. Effect of increasing dried blood cells in corn-soybean meal diets on growth performance of weanling and growing pigs. Prof Anim Sci 2011;27:65-72. https://doi.org/10.15232/S10807446(15)30446-0

8. Dilger RN, Sands JS, Ragland D, Adeola O. Digestibility of nitrogen and amino acids in soybean meal with added soyhulls. J Anim Sci 2004;82:715-24. https://doi.org/10.2527/2004. $823715 \mathrm{x}$

9. Committee on Nutrient Requirements of Swine, National 
Research Council. Nutrient requirements of swine. 11th ed. Washington, DC, USA: National Academies Press; 2012.

10. Association of Official Analytical Chemists. Official methods of analysis. 18th ed. Arlington, VA, USA: Association of Official Analytical Chemists; 2006.

11. Association of Official Analytical Chemists. Official methods of analysis. 17th ed. Arlington, VA, USA: Association of Official Analytical Chemists; 2000.

12. Fenton TW, Fenton M. An improved procedure for the determination of chromic oxide in feed and feces. Can J Anim Sci 1979;59:631-4. https://doi.org/10.4141/cjas79-081

13. Kong C, Adeola O. Invited review: evaluation of amino acid and energy utilization in feedstuff for swine and poultry diets. Asian-Australas J Anim Sci 2014;27:917-25. https:// doi.org/10.5713/ajas.2014.r.02

14. Casas GA, Huang C, Stein HH. Nutritional value of soy protein concentrate ground to different particle sizes and fed to pigs. J Anim Sci 2017;95:827-36. https://doi.org/10. 2527/jas2016.1083

15. Lagos LV, Stein HH. Torula yeast has greater digestibility of amino acids and phosphorus, but not energy, compared with a commercial source of fish meal fed to weanling pigs. J Anim Sci 2020;98:skz375. https://doi.org/10.1093/jas/skz375

16. Almeida FN, Htoo JK, Thomson J, Stein HH. Comparative amino acid digestibility in US blood products fed to weanling pigs. Anim Feed Sci Technol 2013;181:80-6. https:/doi.org/ 10.1016/j.anifeedsci.2013.03.002

17. Wu Y, Pan L, Tian Q, Piao X. Comparative digestibility of energy and ileal amino acids in yeast extract and spray-dried porcine plasma fed to pigs. Arch Anim Nutr 2018;72:76-84. https://doi.org/10.1080/1745039X.2017.1413827

18. Kerr BJ, Urriola PE, Jha R, Thomson JE, Curry SM, Shurson GC. Amino acid composition and digestible amino acid content in animal protein by-product meals fed to growing pigs. J Anim Sci 2019;97:4540-7. https://doi.org/10.1093/ jas/skz294

19. Balan P, Staincliffe M, Moughan PJ. Effects of spray-dried animal plasma on the growth performance of weaned pigletsA review. J Anim Physiol Anim Nutr 2021;105:699-714. https://doi.org/10.1111/jpn.13435

20.Zhang B, Yang W, Zhang H, Meng Q, Bi C, Shan A. Effect of fermented blood cells on growth performance and intestinal characteristics of weaned piglets. J Anim Physiol Anim Nutr 2019;103:1875-84. https://doi.org/10.1111/jpn.13194

21. Park CS, Oh SI, Kim BG. Prediction of basal endogenous losses of amino acids based on body weight and feed intake in pigs fed nitrogen-free diets. Rev Colomb Cienc Pecu 2013; 26:186-92.

22. Adeola O, Xue PC, Cowieson AJ, Ajuwon KM. Basal endogenous losses of amino acids in protein nutrition research for swine and poultry. Anim Feed Sci Technol 2016;221: 274-83. https://doi.org/10.1016/j.anifeedsci.2016.06.004

23. Rojas OJ, Liu Y, Stein HH. Concentration of metabolizable energy and digestibility of energy, phosphorus, and amino acids in lemna protein concentrate fed to growing pigs. J Anim Sci 2014;92:5222-9. https://doi.org/10.2527/jas20148146

24. Jones AM, Wu F, Woodworth JC, et al. Evaluating the effects of fish meal source and level on growth performance of nursery pigs. Transl Anim Sci 2018;2:144-55. https://doi.org/ 10.1093/tas/txy010

25. Gottlob RO, DeRouchey JM, Tokach MD, et al. Amino acid and energy digestibility of protein sources for growing pigs. J Anim Sci 2006;84:1396-402. https://doi.org/10.2527/2006. 8461396x

26. Kim BG, Kil DY, Zhang Y, Stein HH. Concentrations of analyzed or reactive lysine, but not crude protein, may predict the concentration of digestible lysine in distillers dried grains with solubles fed to pigs. J Anim Sci 2012;90:3798-808. https:// doi.org/10.2527/jas.2011-4692 